\title{
PERILAKU PEMECAHAN MASALAH SISWA SMK DALAM MENYELESAIAKAN MASALAH KOMBINATORIKA DITINJAU DARI KECEMASAN MATEMATIKA
}

\author{
Olivia Khufyatul Adhimah ${ }^{1}$, Rooselyna Ekawati ${ }^{2}$ \\ ${ }^{1,2}$ Universitas Negeri Surabaya, Jl. Ketintang, Surabaya, Indonesia \\ Email: oliviaadhimah16030174048@mhs.unesa.ac.id
}

\begin{abstract}
Problem solving behavior has an important role for each student because problem solving behavior can provide a description of student behavior during the process of solving mathematical problems, especially combinatorial problems. Mathematics anxiety can affect mathematical problem solving. Given the importance of problem solving behavior in mathematics learning, the problem solving behavior in solving problem in terms of differences in mathematics anxiety must be undestood. This study aims to determine problem solving behavior in solving combinatorial problems. The subjects of this study were 9 students of SMK Negeri 1 Palang. These students are given math anxiety questionnaires and combinatorial problem solving test questions. The results of this study are combinatorial problem solving behavior of students with high anxiety levels included in the category of Direct Translation Approach not proficient (DTA-np), and combinatorial problem solving behavior of students with low anxiety levels included the category of Meaning Based Approach full context (MBA -fc).
\end{abstract}

Keywords: problem solving behavior, combinatorics, mathematical anxiety

\begin{abstract}
Abstrak
Perilaku pemecahan masalah memiliki peran penting bagi setiap siswa karena perilaku pemecahan masalah dapat memberikan deskripsi perilaku siswa selama proses penyelesaian masalah matematika khususnya masalah kombinatorika. Kecemasan matematika dapat mempengaruhi pemecahan masalah siswa. Mengingat pentingnya perilaku pemecahan masalah matematika dalam pembelajaran matematika, maka guru harus mengetahui perilaku pemecahan masalah siswa dalam menyelesaikan masalah ditinjau dari kecemasan matematika. Penelitian ini bertujuan untuk mengetahui perilaku pemecahan masalah dalam menyelesaikan masalah kombinatorika. Subjek dari penelitian ini adalah siswa SMK Negeri Palang sebanyak 9 siswa. Siswa tersebut diberikan angket kecemasan matematika dan soal tes pemecahan masalah kombinatorika. Hasil dari penelitian ini adalah perilaku pemecahan masalah kombinatorika dari siswa dengan tingkat kecemasan tinggi masuk dalam kategori Direct Translation Approach not proficient (DTA-np), sedangkan perilaku pemecahan masalah kombinatorika dari siswa dengan tingkat kecemasan matematika rendah masuk dalam kategori Meaning Based Approach full context $(M B A-f c)$.
\end{abstract}

Kata Kunci: Perilaku Pemecahan Masalah, Kombinatorika, Kecemasan Matematika

\section{PENDAHULUAN}

Pemecahan masalah termasuk hal yang sangat penting dalam pembelajaran matematika. Hal ini karena pemecahan masalah membangkitkan siswa untuk merespon pertanyaan-pertanyaan yang diajukan, siswa menjadi terampil memilih dan mengidentifikasi kondisi dan konsep yang relevan, mencari generalisasi, merumuskan rencana penyelesaian dan mengorganisasikan keterampilan yang telah dimiliki sebelumnya (Hudojo, 1977). Pemecahan masalah merupakan proses dari individu untuk sebuah soal yang jawabannya belum tampak jelas (Siswono, 2008). Krulik dan Rudnick (1988) menyatakan bahwa "Problem solving is a process. It is means by which an individual uses previously acquired knowledge, skills, and understanding to satisfy the demands of an unfamiliar situation", hal tersebut mendukung pernyataan bahwa pemecahan masalah adalah hal yang sangat penting pada pembelajaran matematika. Namun, penelitian yang ada kebanyakan meneliti pemecahan masalah dari cara menemukan solusi dengan prespektif pemahaman masalah, hanya sedikit yang meneliti tentang 
perilaku pemecahan masalah. Perilaku pemecahan masalah adalah langkah-langkah yang ditunjukkan siswa ketika proses penyelesaian masalah mulai dari cara menghitung hingga menemukan solusi dari masalah tersebut. "A learner's problem solving behaviour could be explained in light of the problem solving characteristics or attributes he/she exhibits (or that can be inferred from his/her verbal or written responses)"(Chirove, 2014). Perilaku pemecahan masalah siswa dapat dijelaskan dengan mempertimbangkan karakteristik atau atribut pemecahan masalah yang ia tunjukkan (atau yang dapat disimpulkan dari tanggapan verbal atau tertulisnya). Hal tersebut menegaskan bahwa perilaku pemecahan masalah dapat dilihat melalui respon siswa baik secara verbal maupun tulisan dalam menyelesaikan masalah.

Salah satu peneliti yang membahas tentang perilaku pemecahan masalah dalam penelitiannya ialah Hegarty (1995). Perilaku pemecahan masalah menurut Hegarty dkk (1995) dibagi menjadi 2 kategori yaitu : (1) Pendekatan Langsung (Direct Translation Approach /DTA), dan (2) Pendekatan Bermakna (Meaning Based Approach /MBA). Selanjutnya menurut Pape (2004) untuk Pendekatan langsung (Direct Translation Approach/DTA) dapat dibagi menjadi 3 sub-kategori yaitu : (1) Direct Translation Approach-proficient (DTA-p), (2) Direct Translation Approach-not proficient (DTA-np), (3) Direct Translation Approach-limited context (DTA-lc). Sedangkan untuk Pendekatan bermakna (Meaning-Based Approach/MBA) dibagi menjadi dua sub-kategori, yaitu : (1) Meaning-Based Approach-full context (MBA-fc), dan (2) Meaning-Based Approach-justification (MBA-j).

Menurut Pape (2004), kategori pendekatan langsung (Direct Translation Approach /DTA) memiliki karakteristik yakni kurangnya kemampuan siswa dalam mentransformasikan informasi dari masalah yang diberikan, termasuk menghubungkan tiap elemen masalah. Siswa mencatat elemen masalah tanpa menggunakan konteks yang disediakan dalam masalah. Siswa hanya menuliskan angkaangka yang diberikan pada masalah tanpa konteks. Akibatnya siswa melakukan perhitungan matematis tanpa merujuk atau membaca ulang masalah. Sedangkan untuk kategori pendekatan bermakna (Meaning Based Approach /MBA) ditandai dengan perilaku transformatif siswa, yang memiliki tiga karakteristik : mencatat informasi yang diberikan, penggunaan konteks, dan terdapat penjelasan dan / atau justifikasi untuk perhitungan matematis. Salah satu perilaku utama siswa ini adalah mencatat informasi yang diberikan dengan konteks yang sesuai. Selain itu, siswa memberikan penjelasan untuk langkah-langkah perhitungan yang dilakukan. Satu subkategori dikarakteristikkan dengan ketentuan penjelasan dan justifikasi untuk langkah perhitungannya. Akhirnya, jawaban terakhir siswa menunjukkan bahwa mereka memahami dan menghubungkannya dengan masalah yang diberikan. Penelitian yang dilakukan oleh Pape (2004) menggunakan masalah yang mengandung konteks. Dan perilaku pemecahan masalah siswa dapat dilihat jika masalah tersebut adalah masalah kontekstual. Kombinatorika merupakan materi yang sangat erat menggunakan konteks sehari-hari.

Masih banyak siswa yang kesulitan memahami masalah matematika, hal itu dapat berdampak pada hasil belajar siswa. Hasil belajar siswa dapat dipengaruhi oleh beberapa faktor yaitu faktor dari dalam dirinya sendiri (faktor internal) dan faktor yang bersal dari luar dirinya (faktor eksternal). Salah 
satu faktor internal yang mungkin terjadi adalah siswa memiliki kecemasan matematika yang tinggi. Kecemasan dalam Kamus Besar Bahasa Indonesia (KBBI) adalah perasaan tidak tentram, khawatir, dan gelisah. Kecemasan merupakan gangguan psikologi yang bersifat wajar dan dapat timbul kapan dan dimanapun. Setiap orang pasti pernah mengalami kecemasan dengan tingkat yang berbeda-beda. Rasa cemas biasanya muncul dikarenakan terdapat suatu keadaan yang harus dihadapi atau diselesaikan.

Kecemasan matematika ialah respon emosional terhadap matematika saat mengikuti kelas matematika, menyelesaikan masalah matematika, dan mendiskusikannya. Freedman (2017) mengemukakan kecemasan matematika sebagai "an emotional reaction to mathematics based on past unpleasant experience which harms future learning". Kecemasan matematika adalah sebuah reaksi emosional terhadap matematika yang didasari oleh pengalaman masa lalu yang tidak menyenangkan yang mana akan mengganggu pembelajaran selanjutnya. Selain itu, menurut Klados dkk (2017) kecemasan matematika ialah perasaan cemas, ketakutan atau kengerian berlebih yan disebabkan oleh peristiwa yang akan datang yan berhubungan dengan matematika. Kecemasan matematika akan mempengaruhi siswa dalam menyelesaikan sebuah soal matematika. Pernyataan tersebut sejalan dengan Kuniawati, dkk (2014) yang menyatakan terdapat hubungan negatif antara kecemasan matematika dengan kemampuan pemecahan masalah, jika kecemasan matematika meningkat maka kemampuan pemecahan masalah menurun.

Berdasarkan pemaparan diatas, peneliti melakukan penelitian dengan judul "Perilaku Pemecahan Masalah Siswa SMK dalam Menyelesaikan Masalah Kombinatorika Ditinjau dari Kecemasan Matematika". Penelitian ini bertujuan untuk mendeskripsikan perilaku pemecahan masalah (1) siswa SMK yang memiliki kecemasan matematika tinggi dalam menyelesaikan masalah kombinatorika, (2) siswa SMK yang memiliki kecemasan matematika rendah dalam menyelesaikan masalah kombinatorika..

\section{METODE}

Penelitian ini merupakan penelitian deskriptif kualitatif. Subjek dari penelitian ini adalah siswa SMK Negeri Palang, Tuban kelas XI sebanyak 9 siswa. 9 siswa tersebut diberikan angket kecemasan matematika dan soal tes pemecahan masalah kombinatorika. Angket kecemasan matematika terdiri dari 15 pernyataan, pernyataan tersebut dibagi menjadi dua kelompok yaitu pernyataan yang favorable (positif) dan pernyataan yang unfavorable (negatif). Soal tes pemecahan masalah kombinatorika terdiri dari 3 soal tentang kaidah pencacahan dan permutasi.

Data diperoleh dari angket kecemasan matematika dan tes pemecahan masalah kombinatorika. Pertama, siswa SMK kelas XI diberikan angket kecemasan matematika selanjutnya diberikan soal tes pemecahan masalah kombinatorika. Pada penelitian ini terdapat 2 kategori kecemasan matematika, yakni kecemasan matematika tinggi (jika skor angket $\geq 43,95$ ) dan kecemasan matematika rendah (jika skor angket $\leq 30,65)$. Untuk menganalisis perilaku pemecahan masalah siswa menggunakan indikator 
dibawah ini :

\section{Tabel 1.}

Indikator Perilaku Pemecahan Masalah Siswa

\begin{tabular}{|l|c|c|c|c|c|}
\hline \multicolumn{1}{|c|}{ Indikator } & DTA-p & DTA-np & DTA-lc & MBA-fc & MBA-j \\
\hline $\begin{array}{l}\text { Terdapat kaitan antara } \\
\text { perhitungan matematis } \\
\text { yang dilakukan dengan } \\
\text { masalah }\end{array}$ & Ya & Tidak & Ya & Ya & Ya \\
\hline $\begin{array}{l}\text { Menggunakan konteks pada } \\
\text { penyelesaiannya }\end{array}$ & Tidak & Tidak & Ya & Ya & Ya \\
\hline $\begin{array}{l}\text { Terdapat penjelasan dalam } \\
\text { perhitungan }\end{array}$ & Tidak & Tidak & Tidak & Ya & Ya \\
\hline Menuliskan jawaban akhir & Ya & Ya & Ya & Ya & Ya \\
\hline $\begin{array}{l}\text { Memberikan alasan pada } \\
\text { setiap langkah }\end{array}$ & Tidak & Tidak & Tidak & Tidak & Ya \\
\hline
\end{tabular}

\section{HASIL DAN PEMBAHASAN}

Berdasarkan analisis data kecemasan matematika pada siswa, terdapat 2 siswa yang memiliki tingkat kecemasan matematika rendah dan terdapat 1 siswa yang memiliki tingkat kecemasan matematika tinggi. Dipilih 1 siswa dari kategori kecemasan matematika rendah dan 1 siswa dari kategori kecemasan matematika tinggi. PKT $=$ Perilaku Pemecahan Masalah dari Siswa dengan tingkat Kecemasan Matematika Tinggi, PKR = Perilaku Pemecahan Masalah dari Siswa dengan tingkat Kecemasan Matematika Rendah.

\section{Tabel 2.}

Kategori Perilaku Pemecahan Masalah Siswa dengan Kecemasan Matematika Tinggi dan Rendah

\begin{tabular}{|c|c|c|c|c|c|c|c|}
\hline \multirow{2}{*}{$\begin{array}{c}\text { Subjek } \\
\text { Penelitian }\end{array}$} & \multirow{2}{*}{$\begin{array}{c}\text { Nomor } \\
\text { Soal }\end{array}$} & \multicolumn{2}{|c|}{ Indikator Perilaku Pemecahan Masalah } & \multirow{2}{*}{ Kategori } \\
\cline { 3 - 7 } & $\mathbf{1}$ & $\mathbf{2}$ & $\mathbf{3}$ & $\mathbf{4}$ & $\mathbf{5}$ & Perilaku \\
\hline PKT & 1 & Tidak & Tidak & Tidak & Ya & Tidak & DTA-np \\
\hline & 2 & Ya & Tidak & Tidak & Ya & Tidak & DTA-p \\
\hline PKR & 3 & Tidak & Tidak & Tidak & Ya & Tidak & DTA-np \\
\hline & 2 & Ya & Ya & Ya & Ya & Tidak & MBA-fc \\
\hline & 3 & Tidak & Tidak & Tidak & Ya & Tidak & DTA-np \\
\hline
\end{tabular}

Perilaku Pemecahan Masalah dari Siswa dengan tingkat Kecemasan Tinggi

Siswa dengan tingkat kecemasan matematika tinggi menyelesaikan soal nomor 1 hanya dengan menggunakan aturan perkalian. 


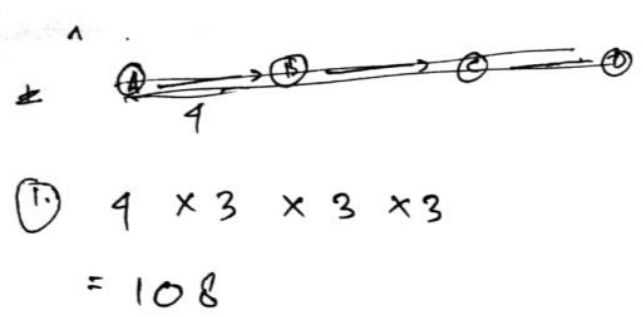

Gambar 1. Jawaban soal nomor 1 oleh PKT

Perilaku pemecahan masalah yang ditunjukkan subjek dengan tingkat kecemasan matematika tinggi dalam menyelesaikan masalah kombinatorika yaitu : (1) siswa tidak dapat menyelesaikan masalah karena perhitungan matematis yang dilakukan tidak ada kaitannya dengan masalah: (2) siswa tidak menggunakan konteks masalah dalam proses penyelesaian atau perhitungan matematis; (3) siswa memberikan jawaban akhirnya tetapi tidak benar dan tidak menggunakan konteks masalah; (4) siswa tidak memberikan penjeleasan pada perhitungan matematis serta tidak memberikan alasan. Hal tersebut menunjukkan perilaku pada kategori Direct Translation Approach not proficient (DTA-np). Namun terdapat juga perilaku yang ditunjukkan subjek dengan kecemasan matematika tinggi, yaitu : (1) siswa secara langsung melakukan perhitungan matematis; (2) siswa tidak menggunakan konteks masalah dalam proses penyelesaian atau perhitungan matematis; (3) siswa menuliskan jawaban akhirnya tetapi tidak menggunakan konteks; (4) siswa tidak memberikan penjelasan pada perhitungan matematisnya serta tidak memberikan alasan. Hal tersebut menunjukkan perilaku pada kategori Direct Translation Approach proficient (DTA-p).

Perilaku Pemecahan Masalah dari Siswa dengan tingkat Kecemasan Rendah

Siswa dengan tingkat kecemasan matematika rendah menyelesaikan soal nomor 1 dengan menggunakan aturan perkalian dan penjumlahan.

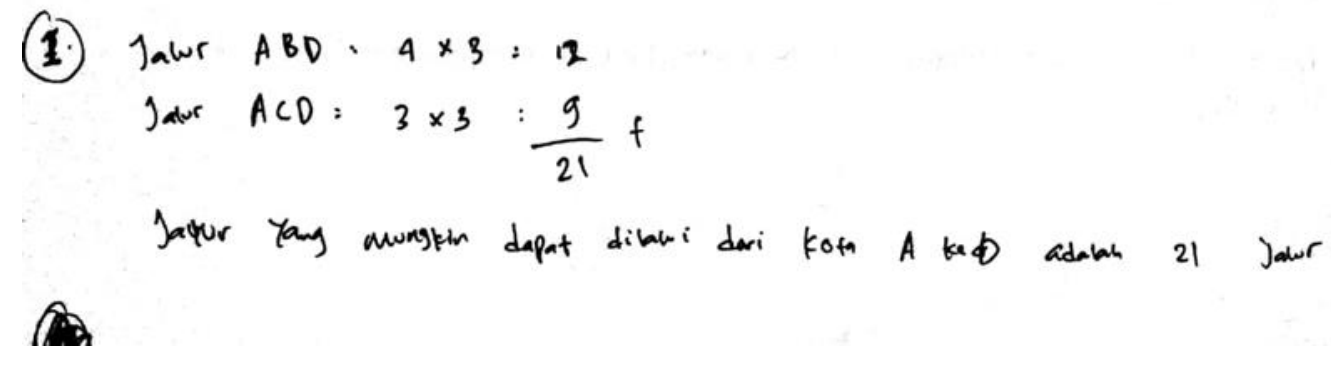

Gambar 2. Jawaban soal nomor 1 oleh PKR

Perilaku pemecahan masalah yang ditunjukkan subjek dengan tingkat kecemasan matematika rendah dalam menyelesaikan masalah kombinatorika yaitu : (1) siswa menggunakan konteks masalah dalam proses penyelesaian atau perhitungan matematis; (2) 
siswa menuliskan jawaban akhirnya dengan kalimat lengkap, menggunakan pemahaman dari jawaban dalam konteks masalah; (4) siswa tidak memberikan penjelasan pada perhitungan matematisnya serta tidak memberikan alasan. Hal tersebut menunjukkan perilaku pada kategori Meaning Based Approach full context (MBA-fc).

Hasil penelitian ini sejalan dengan penelitian yang dilakukan oleh Avinie, dkk (2013). Penelitian tersebut menunjukkan bahwa perilaku pemecahan masalah siswa dengan kemampuan matematika tinggi masuk pada kategori Meaning Based Approach full context (MBA-fc. Dan menurut Karasel, dkk (2010) hubungan antara kecemasan matematika dan kemampuan pemecahan masalah adalah korelasi negatif. Hal itu berarti semakin tinggi kecemasan matematika semakin rendah kemampuan siswa dalam menyelesaikan masalah. Maka dapat dikatakan bahwa siswa dengan tingkat kecemasan rendah memilliki kemampuan matematika tinggi dan perilaku pemecahan masalahnya masuk ke dalam kategori Meaning Based Approach full context (MBA-fc).

\section{KESIMPULAN}

Berdasarkan hasil penelitian dapat diperoleh perilaku pemecahan masalah kombinatorika dari siswa dengan tingkat kecemasan matematika tinggi sebagai berikut : (1) siswa tidak dapat menyelesaikan masalah karena perhitungan matematis yang dilakukan tidak ada kaitannya dengan masalah: (2) siswa tidak menggunakan konteks masalah dalam proses penyelesaian atau perhitungan matematis; (3) siswa memberikan jawaban akhirnya tetapi tidak benar dan tidak menggunakan konteks masalah; (4) siswa tidak memberikan penjeleasan pada perhitungan matematis serta tidak memberikan alasan. Hal tersebut menunjukkan perilaku pemecahan masalah kombinatorika dari siswa dengan tingkat kecemasan matematika tinggi masuk dalam kategori Direct Translation Approach not proficient (DTA-np). Sedangkan perilaku pemecahan masalah kombinatorika dari siswa dengan tingkat kecemasan matematika rendah adalah : (1) siswa menggunakan konteks masalah dalam proses penyelesaian atau perhitungan matematis; (2) siswa menuliskan jawaban akhirnya dengan kalimat lengkap, menggunakan pemahaman dari jawaban dalam konteks masalah; (4) siswa tidak memberikan penjelasan pada perhitungan matematisnya serta tidak memberikan alasan. Hal tersebut menunjukkan perilaku pemecahan masalah kombinatorika dari siswa dengan tingkat kecemasan matematika rendah masuk dalam kategori Meaning Based Approach full context $(M B A-f c)$. 


\section{DAFTAR PUSTAKA}

Avinie, N. F., Johan. (2013). Analisis Perilaku Pemecahan Masalah Pada Siswa Dalam Menyelesaikan Soal Cerita Matematika Materi Segiempat Kelas VII SMPN 7 Surabaya. Jurnal Ilmiah Pendidikan Matematika.

Chirove, M. (2014). Relationship Between Learners' Mathematics-Related Belief Systems And Their Approaches To Non-Routine Mathematical Problem Solving: A Case Study Of Three High Schools In Tshwane North District (D3), South Africa. University Of South Africa.

Freedman, E. (2017). Definition of Math Anxiety. Diambil 7 Desember 2019, dari http://www.mathpower.com/anxtest.htm

Hegarty, M., Mayer, R., \& Monk, C. A. (1995). Comprehension of arithmetic word problems: A comparison of successful and unsuccessful problem solvers. Journal of Educational Psychology, 87, 18-32.

Hudojo, Herman. (1977). Belajar Mengajar Matematika. Jakarta: Direktorat Jenderal Pendidikan Tinggi PPLPTK.

Kamus Besar Bahasa Indonesia (KBBI). Arti kata kecemasan. Kamus Besar Bahasa Indonesia (KBBI) Online.

Karasel, N., Ayda, O., \& Tezer, M. (2010). The relationship between mathematics anxiety and mathematical problem solving skills among primary school students. Procedia-Social and Behavioral Sciences, 2(2), 5804-5807.

https://doi.org/10.1016/j.sbspro.2010.03.946

Klados, Manousos A., Niki Pandria, Sifis Micheloyannis, Daniel Margulies, dan Panagiotis D. Bamidis. (2017). Math Anxiety: Brain Cortical Network Changes in Anticipation of Doing Mathematics. International Journal of Psychophysiology, 122 (December), 24-31.

Krulik, S., \& Rudnick, J.A. (1988). Problem Solving: A Handbook for Elementary School Teacher. https://doi.org/10.1017/CBO9781107415324.004

Kurniawati, Annisa Dwi dan Siswono, T. E. Y. (2014). Pengaruh Kecemasan dan Self Efficacy Siswa Terhadap Kemampuan Pemecahan Masalah Materi Segiempat Siswa Kelas VII MTs Negeri Ponorogo. Jurnal Ilmiah Pendidikan Matematika.

Pape, Stephen J. (2004). Middle School Children's Problem Solving Behavior: A Cognitive Analysis from a Reading Comprehension Perspective. Journal for Research in Mathematics Education. National Council of Teachers of Mathematics.

Siswono, T. Y. E. (2008). Model pembelajaran matematika berbasis pengajuan dan pemecahan masalah untuk meningkatkan kemampuan berpikir kreatif. Surabaya: Unesa University Press. 